\title{
Tracing anthropogenic carbon dioxide and methane emissions to fossil fuel and cement producers, 1854-2010
}

\author{
Richard Heede
}

Received: 5 March 2013 / Accepted: 14 October 2013 /Published online: 22 November 2013

(C) The Author(s) 2013. This article is published with open access at Springerlink.com

\begin{abstract}
This paper presents a quantitative analysis of the historic fossil fuel and cement production records of the 50 leading investor-owned, 31 state-owned, and 9 nation-state producers of oil, natural gas, coal, and cement from as early as 1854 to 2010 . This analysis traces emissions totaling $914 \mathrm{GtCO}_{2} \mathrm{e}-63 \%$ of cumulative worldwide emissions of industrial $\mathrm{CO}_{2}$ and methane between 1751 and 2010 - to the 90 "carbon major" entities based on the carbon content of marketed hydrocarbon fuels (subtracting for non-energy uses), process $\mathrm{CO}_{2}$ from cement manufacture, $\mathrm{CO}_{2}$ from flaring, venting, and own fuel use, and fugitive or vented methane. Cumulatively, emissions of $315 \mathrm{GtCO}_{2} \mathrm{e}$ have been traced to investor-owned entities, $288 \mathrm{GtCO}_{2} \mathrm{e}$ to state-owned enterprises, and $312 \mathrm{GtCO}_{2} \mathrm{e}$ to nation-states. Of these emissions, half has been emitted since 1986. The carbon major entities possess fossil fuel reserves that will, if produced and emitted, intensify anthropogenic climate change. The purpose of the analysis is to understand the historic emissions as a factual matter, and to invite consideration of their possible relevance to public policy.
\end{abstract}

\section{Introduction}

It is now broadly accepted that anthropogenic climate change presents a serious threat to the health, prosperity, and stability of human communities, and to the stability and existence of non-human species and ecosystems (IPCC 2007; World Bank 2012b; Hoeppe 2011; Busby 2007). The international legal framework established in 1992 to prevent "dangerous anthropogenic interference" with the climate system has focused attention on the role of nation-states, and has led to commitments by many nation-states (particularly the Annex I or highly developed nations) to cut their greenhouse gas (GHG) emissions. However, current climate change is primarily driven by historic emissions (Allen et al. 2009b; Matthews et al. 2009; Wei et al. 2012; IPCC 2013), and the parties responsible for the dominant sources of historic emissions are not necessarily the same as those responsible for the dominant share of current emissions. This paper provides an original quantitative analysis of historic emissions by

None of the material in this paper has been published or is under consideration elsewhere.

Electronic supplementary material The online version of this article (doi:10.1007/s10584-013-0986-y) contains supplementary material, which is available to authorized users.

R. Heede $(\bowtie)$

Climate Accountability Institute, 1626 Gateway Road, Snowmass, CO 81654, USA

e-mail: heede@climatemitigation.com 
tracing sources of industrial $\mathrm{CO}_{2}$ and methane to the 90 largest corporate investor-owned and state-owned producers of fossil fuels and cement from as early as 1854 to 2010. The purpose of this analysis is to understand those historic emissions as a factual matter, to invite consideration of their possible relevance to public policy, and to lay the possible groundwork for apportioning responsibility for climate change to the entities that provided the hydrocarbon products to the global economy.

\section{International policy and historic emissions}

Cumulative historic emissions have caused persistently higher atmospheric concentration of carbon dioxide and other GHG emissions (Matthews et al. 2009; Zickfeld et al. 2010). While atmospheric concentrations of $\mathrm{CO}_{2}$ can be lowered in several ways, it is generally agreed that to avoid further dangerous anthropogenic interference in the climate system, net future emissions must be reduced from business-as-usual projections. Parties to the United Nations Framework Convention on Climate Change (UNFCCC 1992, "Framework Convention") agreed that developed nations "on the basis of equity and in accordance with their common but differentiated responsibilities ... should take the lead in combating climate change and the adverse effects thereof." By "differentiated" it was recognized that Annex I nations had produced most of the GHG emissions, and therefore were responsible for taking the first steps in reducing emissions. Numerous proposals on equitable distribution of burdens and remedies for climate change have been made. These include equal per capita allocation over time (Baer et al. 2000; Bode 2004), contraction and convergence toward a common per capita emission rate at a predetermined year (Global Commons Institute 2008), common but differentiated convergence with favorable allowances for non-Annex I countries (Höhne et al. 2006), multicriteria regimes that account for historic responsibility, capability to contribute, and needs, such as poverty alleviation (Ringius et al. 2002), and remaining $\mathrm{CO}_{2}$ and methane "debt" from historic emissions (Smith et al. 2013). Ignoring historic emissions that disadvantage poorer nations violate the principle embodied in the 1972 UN Conference on the Human Environment that nation-states' "sovereign right to exploit their own resources" is subject to not causing "damage to the environment of other states." (Neumayer 2000).

One of the proposals that account for historic emissions is the Brazilian Proposal, analyzed by the UNFCCC Subsidiary Body for Scientific and Technical Advice (SBSTA) in the run-up to Kyoto, which suggested that the burden of addressing climate change should be apportioned on the basis of the temperature response from national historic $\mathrm{CO}_{2}$ emissions (den Elzen et al. 2005; Rive et al. 2006; Baumert and Kete 2002). Such equity-based proposals argue, in part, that wealth is closely tied to historic energy use and therefore to historic emissions and attributed radiative forcing, and it is appropriate to apportion greater responsibility for emissions reductions to the nations that became wealthy in large part by consuming, and in many cases producing, the carbon fuels for the world market (Gardiner 2004; Jamieson 2009).

Annex I countries rejected this argument on the grounds that they could not be held responsible for emissions made prior to 1990, when the Intergovernmental Panel on Climate Change (IPCC) first warned that greenhouse gas emissions were contributing to global warming. In essence, they argued that they could not be held responsible for a problem they did not yet know existed. This argument ignores the many scientific warnings published in the 1960s, 1970s, and 1980s (President's Science Advisory Committee 1965; Matthews et al. 1971; Broecker 1975; World Meteorological Organization 1976; National Research Council 1979; U.S. EPA 1983; see discussion in Weart 2003; Fleming 2005; Oreskes and Conway 2010). In addition, many countries, including Brazil and the United States, have laws 
embracing the legal principle of "objective responsibility" by which a polluter cannot escape responsibility by claiming ignorance of environmental damages (La Rovere et al. 2002; Gardiner 2011).

\section{A new approach: tracing emissions to producers}

The question of wealth generated through the production and use of fossil fuels suggests an alternative to the nation-state approach: to analyze emissions in terms of the fossil fuels produced by incorporated entities - such as investor-owned or state-owned companies - rather than states as consumers and emitters. This perspective calls attention to the fact that substantial emissions have come from fossil fuels sourced from non-Annex I countries such as China, India, Saudi Arabia, South Africa, Iran, Brazil, and Mexico, and from nations that are not large scale emitters, such as Nigeria, Venezuela, Kuwait, Angola, Malaysia, and Libya. The Framework Convention apportions responsibility to the wealthy Annex I nations that have benefited most from using fossil fuels. However, considerable wealth has also accumulated to nations and companies that produce the fuels sold on the international market. For this reason, the present analysis focuses on the world's largest investor-owned and state-owned carbon producers, whether situated in Annex I or non-Annex I nations, and invites consideration of the suggestion that some degree of responsibility for both cause and remedy for climate change rests with those entities that have extracted, refined, and marketed the preponderance of the historic carbon fuels.

\section{Analysis and methods}

For tractability, a threshold of $\geq 8$ million tonnes carbon per year ( $\mathrm{MtC} / \mathrm{y})$ for fossil fuel production was established. This resulted in the identification of 90 entities: 50 of which are investor-owned companies, 31 are state-owned enterprises, and 9 are current or former centrally planned states. Of these 90 entities 56 are crude oil and natural gas producers, 37 are coal extractors (including subsidiaries of oil \& gas companies), and 7 are cement producers. Headquartered in 43 countries, these entities extract resources from every oil, natural gas, and coal province in the world, and process the fuels into marketable products that are sold to consumers in every nation on Earth.

Company production records were retrieved from publicly available annual reports from university and public library collections in Europe, North America, Africa, and Asia, from company websites, company reports filed with the U.S. Securities and Exchange Commission, company histories, and other sources. The carbon content of each entity's annual production of coal, oil and natural gas liquids, and natural gas was calculated using IPCC, United Nations, International Energy Agency (IEA), and U.S. Environmental Protection Agency (EPA) carbon factors to quantify the annual emissions traceable to each entity. Historically complete records were sought from the earliest records available (the earliest is from 1854) through 2010. Where mergers or acquisitions occurred, carbon production and emissions prior to the date of acquisition are attributed to the extant company.

Since the objective of the analysis is to estimate carbon entering the atmosphere, two important calculations are made. The first is for non-combustion uses of hydrocarbon products.

For crude oil and natural gas liquids (NGLs), non-energy uses include petrochemicals, lubricants, road oil, waxes, solvents, and other industrial uses; for natural gas they include fertilizer production and pharmaceuticals; and for coal include pigments, carbon fibers, and 
steel making. These non-combustion uses effectively store carbon, and thus must be subtracted from the emission calculations. The net storage rates were derived from 1980 to 2010 data on non-energy uses in the United States following the IPCC inventory and carbon storage protocols (Environmental Protection Agency 2012a, b; IPCC 2006). Short-term combustion of petrochemical products such as plastics in waste-to-energy plants, synthetic tires burned in cement kilns, recycled lubricating oils used as fuel (or oxidized in normal use), wax burning, petroleum coke used in refineries, special naphthas volatilized in paints, and other uses are credited back to the oxidation column in determining the final storage and emission rates for each fuel type. The final net storage rates are $8.02 \%$ for liquids, $1.86 \%$ for natural gas, and $0.016 \%$ for coal.

The analysis accounts for the carbon content of each fuel, and therefore the $\mathrm{CO}_{2}$ released on combustion to the atmosphere. This is particularly important for coal, since producers report physical quantities rather than heating values (i.e., tons, barrels, or cubic feet rather than energy content). The carbon content factors for each fuel follow international guidelines. The carbon content varies most for coal-from $\sim 33 \%$ carbon for lignites to $\sim 72 \%$ carbon for anthracites - and the rank of produced coal is noted when reported. In many cases producers provided scant guidance on heating values or rank of coal mined, instead using generic labels such as "thermal coal" or "metallurgical coal," in which cases the average IPCC values for these fuels have been applied. (See Supplementary Materials).

Additional emission sources attributable to oil, gas, and coal operations include $\mathrm{CO}_{2}$ vented from processing of raw (sour) natural gas, $\mathrm{CO}_{2}$ from gas flaring (typical at oil production sites where gas is stranded), and fugitive or vented methane from oil and gas operations and coal mining. These emission rates were derived from IPCC Tier 1 factors and corroborated with EPA data on $\mathrm{CO}_{2}$ and $\mathrm{CH}_{4}$ leakage, flaring, and venting rates (IPCC 2006; EPA 2012a, b), flaring data from the World Bank (World Bank 2012a), and coal mine methane venting rates using data from U.S. and international sources (EPA 2011, 2012b; Stern and Kaufmann 1998; European Commission 2011). Operational emission rates vary across the global oil, gas, and coal industries by country, company, field location, offshore vs. onshore, surface vs. underground coal mining, and decade of production. In all cases, the factors applied to each producing entity are within the ranges proscribed by credible international sources.

The emission factors, methodology, and results are compared to the Carbon Dioxide Information Analysis Center's (CDIAC) database of global $\mathrm{CO}_{2}$ emissions from 1751 to the present (Marland and Rotty 1984; Marland et al. 2011). Methane emission rates are compared to the European Commission's Joint Research Centre's EDGAR database of global $\mathrm{CH}_{4}$ emissions by source from 1970 to 2008 (extrapolated to 2010; Stern \& Kaufmann methane data for 1860-1969). (See Supplementary Materials, and Heede 2013). A global warming potential for methane of $21 \times \mathrm{CO}_{2}$ (100-year time horizon) is used (IPCC 1996).

Seven cement manufacturers - six investor-owned companies in Japan, Switzerland, France, Germany, Italy, and Mexico, plus China - contributed process emissions from the calcining of limestone $\left(\mathrm{CaCO}_{3} \rightarrow \mathrm{CaO}+\mathrm{CO}_{2}\right)$. Emissions of $\mathrm{CO}_{2}$ from energy inputs to kilns and power plants are excluded. The data is for 1990 to 2010, except China (from 1928). Calcining emissions are from industry data submitted to the World Business Council for Sustainable Development's Cement Sustainability Initiative (WBCSD 2011).

\section{Conservatisms, caveats, and uncertainties}

Production data and thus attributed emissions are generally conservative. Early production records are not always available, emission factors are typically at or below international values, 
non-energy uses were far lower in the early decades than the applied sequestration factor of $8 \%$ for petroleum products (thus emissions would have been commensurately higher), natural gas production was often not reported by producers prior to 1930 (gas was a low-value fuel in the early 20th century, and often flared or vented to the atmosphere); accidental spills, "upset conditions," and emissions from acts of sabotage or war have been excluded from this analysis. $\mathrm{CO}_{2}$ emissions by the cement industry do not cover production prior to 1990 (except for China). Consequently, this study underreports fossil fuel and cement production compared to the actual history of production by nearly all of the carbon major entities. Unpublished company records (if released) may fill in these reporting gaps in the future.

Potential sources of double-counting of oil and gas production have been minimized. Many oil majors only reported gross rather than net or equity production in the 1950s to mid-1970s; this analysis estimates net production by applying a net-to-gross ratio to those companies that reported only gross production for selected years, based on each entity's reporting of both net and gross production in later years. Many state-owned oil companies report production in part attributable to their international joint venture or production-sharing partners, or is otherwise ambiguous or incomplete and often report total oil and gas production within the nation's territory or territorial waters. The details of production-sharing agreements, concessions, and joint ventures are not publicly available, but each state-owned entity has been analyzed in terms of dates of nationalization, equity buy-outs or asset seizures, and fractional shares of national production to the extent this is publicly available (Victor et al. 2012; Marcel 2006; World Bank 2008). Complete reporting by both investor-owned and state-owned companies on equity or working interest production will remove any remaining inaccuracies. (See Supplementary Materials and Heede 2013).

Attributed methane emissions are conservative relative to global coal industry methane emissions ( $38 \%$ of coal-related methane versus $51 \%$ of global coal production). IPCC default methane emission rates (which are 16 times higher for underground mining than for opencast) are applied to all carbon major coal entities; this factor is scaled to the proportion of production by mining method (60\% underground, and $40 \%$ opencast) (IPCC 2006; World Coal Association 2005). However, coal operators often do not specify opencast or underground production, and carbon major entities may be attributed methane emissions that are substantially lower than their actual emissions, or vice-versa. In addition, operators differ on direct venting versus flaring or utilizing the methane, and company reporting on methane generation, venting, and disposition is generally poor.

Factors for non-energy uses and direct emission of $\mathrm{CO}_{2}$ from flaring and venting and fugitive methane are based on international standards and data (IPCC 2006; U.S. EPA 2012b; European Commission 2011; United Nations 2012; see Heede 2013). These are applied to each entity, for each fuel, and for each year, but the operations of individual companies often vary from international norms. Attributed methane, vented $\mathrm{CO}_{2}$, and flaring emissions are conservative relative to international data on emission rates (IPCC 2006; Marland et al. 2011; European Commission 2011).

This study includes energy consumption and emissions from the oil and gas industry's use of its own fuels at a rate of $5.9 \%$ of natural gas production, less than the 9.5 to $10 \%$ of combined oil and natural gas production estimated for the oil and gas supply chain by the International Petroleum Industry Environmental Conservation Association (IPIECA 2011).

Uncertainty ranges are difficult to estimate given the variety of producing entities, reporting quality and completeness, and the additional emission sources applied to entities with differing operating characteristics. Overall, however, the total emissions attributed to the fossil fuel producers in this study are in close agreement with CDIAC estimates in proportion to fuel production data for 1980-2010 ( $-2.3 \%$ for crude oil \& NGLs, $+1.0 \%$ 
for natural gas, and $+3.3 \%$ for coal). The uncertainties are mainly a result of incomplete or unclear reporting by the fossil fuel and cement producers.

\section{Results: "carbon majors"}

A total of 914 billion tonnes of $\mathrm{CO}_{2}$-equivalent $\left(\mathrm{GtCO}_{2} \mathrm{e}\right)$ has been traced to 90 international entities based on analysis of historic production records dating from 1854 to 2010. These entities cumulatively produced 985 billion barrels (bbl) of crude oil and NGLs (79 billion bbl were used for non-energy products), 2,248 trillion cubic feet (Tcf), and 163 billion tonnes of various ranks of coal. The emissions traced to the carbon majors represent $63 \%$ of global industrial $\mathrm{CO}_{2}$ and methane from fossil fuel combustion, flaring, venting, fugitive or vented methane, own fuel use, and cement between 1751 and 2010 (Fig. 1; Table 1). The top source is $366 \mathrm{GtCO}_{2}$ from the combustion of oil products from 55 entities representing $77.5 \%$ of the global CDIAC estimate of oil emissions (Tables 1 and 2; Marland et al. 2011).

Of total industrial $\mathrm{CO}_{2}$ and $\mathrm{CH}_{4}$ emissions from 1751 to 2010, one-half has been emitted since 1984 (Marland et al. 2011). Of the emissions traced to carbon major fossil fuel and cement production, half has been emitted since 1986 (Fig. 1). Cumulatively, emissions of 315 $\mathrm{GtCO}_{2} \mathrm{e}$ have been traced to investor-owned entities, $288 \mathrm{GtCO}_{2} \mathrm{e}$ to state-owned companies, and $312 \mathrm{GtCO}_{2} \mathrm{e}$ to nation-states (Fig. 2). The dip in relative production by nation-states in the late 1980s through early 2000s is due to the collapse of the Soviet Union and the creation of new state-owned oil and natural gas entities in Russia as well as the transformation of China's petroleum sector into state-owned entities.

Cumulative emissions attributed to the twenty largest investor-owned and state-owned energy companies between 1854 and 2010 total $428 \mathrm{GtCO}_{2} \mathrm{e}$, or $29.5 \%$ of global industrial emissions from 1751 to 2010 (Table 3). The ten largest investor-owned companies alone contributed $230 \mathrm{GtCO}_{2} \mathrm{e}$, or $15.8 \%$ of global emissions through 2010. (See Supplementary Materials for results on all 90 entities.)

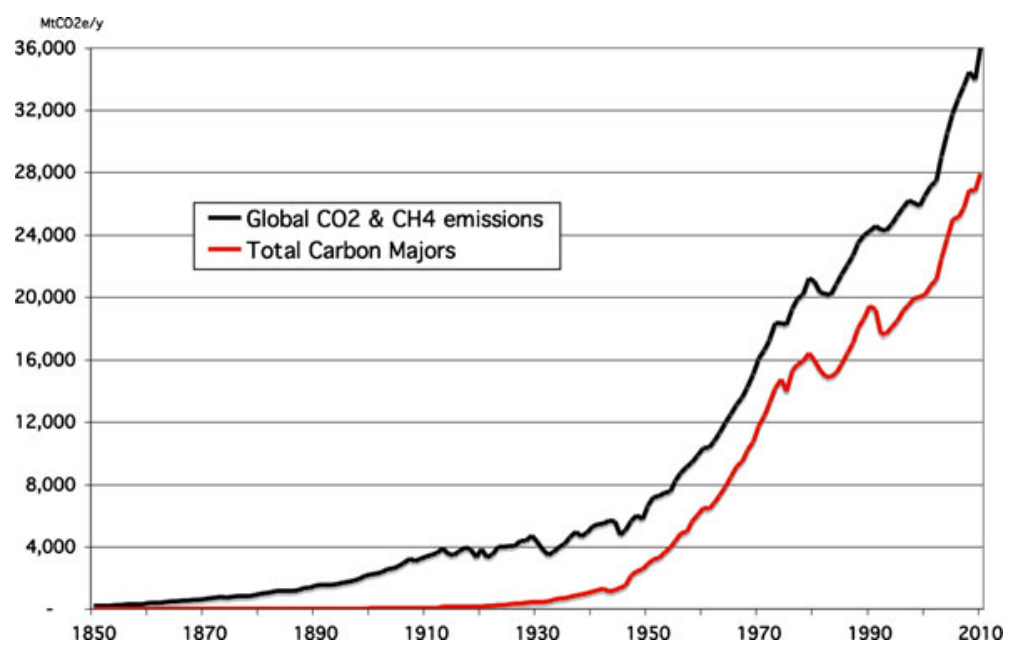

Fig. 1 Global and Carbon Major entities' $\mathrm{CO}_{2}$ emissions, 1850-2010. Global industrial emissions of $\mathrm{CO}_{2}$ from CDIAC plus methane from Stern \& Kaufmann \& European Commission (black line). Results of all Carbon Major entities' emissions of $\mathrm{CO}_{2}$ and methane (red line) 
Table 1 Industrial $\mathrm{CO}_{2}$ and $\mathrm{CH}_{4}$ emissions: comparing this study to CDIAC data $1751-2010$

Global $\mathrm{CO}_{2}$ combustion data is from CDIAC; methane is from Stern \& Kaufmann and European Commission data

\begin{tabular}{lccl}
\hline & $\begin{array}{l}\text { Carbon majors } \\
1854-2010 \\
\mathrm{GtCO}_{2} \mathrm{e}\end{array}$ & $\begin{array}{l}\text { CDIAC } \\
1751-2010 * \\
\mathrm{GtCO}_{2} \mathrm{e}\end{array}$ & $\begin{array}{l}\text { Carbon } \\
\text { majors } \\
\% \text { of global }\end{array}$ \\
\hline Oil \& NGLs & 365.7 & 472.0 & $77.5 \%$ \\
Natural gas & 120.1 & 176.1 & $68.2 \%$ \\
Coal & 329.6 & 642.5 & $51.3 \%$ \\
Flaring & 6.0 & 12.6 & $47.9 \%$ \\
Cement & 13.2 & 32.5 & $40.6 \%$ \\
VentedCO & 4.8 & na & na \\
Own fuel use & 7.1 & na & na \\
Fugitive methane & 67.6 & 114.6 & $59.0 \%$ \\
Sum & 914.3 & $1,450.3$ & $63.0 \%$
\end{tabular}

\section{Discussion}

Parties to the Framework Convention agreed in 1992 that Annex I nations would shoulder most of the burden of funding international negotiations, paying adaptation costs for the poorest nations, and taking the lead in combating climate change, on the basis of the argument that they had benefitted the most from being the largest historical emitters, and therefore had the greatest responsibility for addressing it. This regime has so far failed to reduce global GHG emissions (Olivier et al. 2012; Peters et al. 2012; IEA 2012a; Victor 2009; Höhne et al. 2011), and some observers have concluded that the process is at an impasse (Victor 2011; Schiermeier 2012; Rogelj et al. 2010).

While not disputing the logic of the UNFCCC, the analysis presented here suggests a somewhat different, and perhaps useful, way to consider responsibility for climate change. The analysis highlights the fact that major producers of fossil fuels are not all located in Annex I

Table 2 Carbon majors cumulative emissions 1854-2010, by source category

\begin{tabular}{lrrr}
\hline & Entities & $\begin{array}{l}\text { Total } \\
\text { emissions } \\
\text { Combustion }\end{array}$ & $\begin{array}{l}\text { Percent of } \\
\text { Carbon } \\
\text { Majors }\end{array}$ \\
\hline Oil \& NGLs & 55 & 365.73 & $40.00 \%$ \\
Natural gas & 56 & 120.11 & $13.14 \%$ \\
Coal & 36 & 329.60 & $36.05 \%$ \\
Flaring & 56 & 6.04 & $0.66 \%$ \\
Own fuel use & 56 & 7.12 & $0.78 \%$ \\
Cement & 7 & 13.21 & $1.45 \%$ \\
Vented CO 2 & 54 & 4.83 & $0.53 \%$ \\
Fugitive methane & 83 & 67.62 & $7.40 \%$ \\
Total & 90 & 914.25 & $100.0 \%$ \\
CDIAC global emissions 1751-2010 & & $1,450.33$ & \\
Carbon Majors of global emissions & \multicolumn{4}{c}{$63.04 \%$} \\
\hline
\end{tabular}




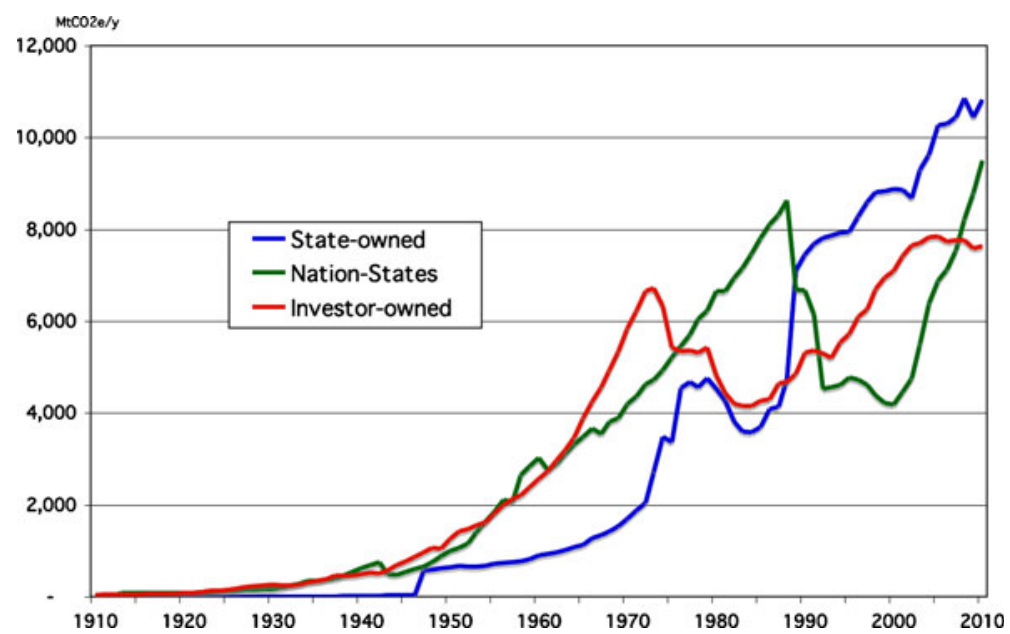

Fig. 2 Carbon Majors' emissions by ownership category, 1910-2010. The total historic contributions of each ownership category are nearly equal: $34.4 \%$ investor-owned (red), $34.1 \%$ nation-states (green), and $31.5 \%$ state-owned (blue), but the proportions vary over time

nations: Saudi Arabia, Iran, China, India, Venezuela, Mexico, Kuwait, Abu Dhabi, and Algeria appear on the list of top twenty producers (Table 3). Of the 85 extant entities, 54 are headquartered in Annex I countries, and 31 in non-Annex I nations. Considerable benefits have accrued to these carbon majors, and to their state-sponsors and investors. Given this, it seems reasonable to argue that they have an ethical obligation to help address climate destabilization (Gardiner et al. 2010; Gardiner 2011). Moreover, many of these entities - both state- and investor-owned-possess the financial resources and technical capabilities to develop and contribute to climate change mitigation and adaptation.

The full menu or analysis of mitigation, adaptation, and climate amelioration options available to the global carbon industry is beyond the scope of this paper. A partial list includes developing carbon capture and storage capacity (Allen et al. 2009a), funding adaptation programs (such as the UNFCCC Adaptation Fund), investing in or developing technologies and programs to realize the enormous global potential for efficient use of carbon fuels (Lovins 2011), developing low- or zero-carbon alternative fuels and power generation systems, funding geo-engineering research, publicly committing to capture and store or remove carbon dioxide from the atmosphere commensurate with their historic emissions, supporting international climate diplomacy and domestic climate legislation (as leading multinational oil and gas companies have begun to do), and, in the event liability for historic and/or future emissions is not averted, setting aside financial reserves to cover potential climate liability claims. Greater transparency, including comprehensive reporting of all direct and product-related emissions, and full disclosure to investors of potential liabilities stemming from company operations or products, material risks to company assets, or material threats to future profits from climate change is warranted (Hancock 2005; Coburn et al. 2011).

Focusing, for a moment, on the possibility of future efforts to capture and store carbon, note that most of the entities highlighted in this analysis have the technical and institutional capabilities necessary to lead research and development in carbon capture and storage or to 
Table 3 Top twenty investor- \& state-owned entities and attributed $\mathrm{CO}_{2} \& \mathrm{CH}_{4}$ emissions

Right column compares each entity's cumulative emissions to CDIAC's global emissions 17512010. Excludes British Coal, whose production and assets have not been attributed to extant companies, and five of nine nation-states (FSU, China, Poland, Russian Federation, and Czechoslovakia, in that order)

\begin{tabular}{|c|c|c|c|}
\hline & $\begin{array}{l}2010 \\
\text { emissions }\end{array}$ & $\begin{array}{l}\text { Cumulative } \\
1854-2010\end{array}$ & $\begin{array}{l}\text { Percent } \\
\text { of global }\end{array}$ \\
\hline Entity & $\mathrm{MtCO}_{2} \mathrm{e}$ & $\mathrm{MtCO}_{2} \mathrm{e}$ & $1751-2010$ \\
\hline 1. Chevron, USA & 423 & 51,096 & $3.52 \%$ \\
\hline 2. ExxonMobil, USA & 655 & 46,672 & $3.22 \%$ \\
\hline 3. Saudi Aramco, Saudi Arabia & 1,550 & 46,033 & $3.17 \%$ \\
\hline 4. BP, UK & 554 & 35,837 & $2.47 \%$ \\
\hline 5. Gazprom, Russian Federation & 1,371 & 32,136 & $2.22 \%$ \\
\hline $\begin{array}{l}\text { 6. Royal Dutch/Shell, } \\
\text { Netherlands }\end{array}$ & 478 & 30,751 & $2.12 \%$ \\
\hline 7. National Iranian Oil Company & 867 & 29,084 & $2.01 \%$ \\
\hline 8. Pemex, Mexico & 602 & 20,025 & $1.38 \%$ \\
\hline 9. ConocoPhillips, USA & 359 & 16,866 & $1.16 \%$ \\
\hline 10. Petroleos de Venezuela & 485 & 16,157 & $1.11 \%$ \\
\hline 11. Coal India & 830 & 15,493 & $1.07 \%$ \\
\hline 12. Peabody Energy, USA & 519 & 12,432 & $0.86 \%$ \\
\hline 13. Total, France & 398 & 11,911 & $0.82 \%$ \\
\hline 14. PetroChina, China & 614 & 10,564 & $0.73 \%$ \\
\hline 15. Kuwait Petroleum Corp. & 323 & 10,503 & $0.73 \%$ \\
\hline 16. Abu Dhabi NOC, UAE & 387 & 9,672 & $0.67 \%$ \\
\hline 17. Sonatrach, Algeria & 386 & 9,263 & $0.64 \%$ \\
\hline 18. Consol Energy, Inc., USA & 160 & 9,096 & $0.63 \%$ \\
\hline 19. BHP-Billiton, Australia & 320 & 7,606 & $0.52 \%$ \\
\hline $\begin{array}{l}\text { 20. Anglo American, United } \\
\text { Kingdom }\end{array}$ & 242 & 7,242 & $0.50 \%$ \\
\hline Top 20 IOCs \& SOEs & 11,523 & 428,439 & $29.54 \%$ \\
\hline Top 40 IOCs \& SOEs & & 546,767 & $37.70 \%$ \\
\hline All 81 IOCs \& SOEs & 18,524 & 602,491 & $41.54 \%$ \\
\hline Total 90 carbon majors & 27,946 & 914,251 & $63.04 \%$ \\
\hline Total global emissions & 36,026 & $1,450,332$ & $100.00 \%$ \\
\hline
\end{tabular}

participate in other proactive climate mitigation programs. This analysis could provide a basis for calculating the amounts of carbon that would have to be captured and stored by various entities to compensate for their contributions to climate change to date, thus providing a factual basis for thinking through what a fair proposal might look like.

Finally, and perhaps most important, the extant carbon major entities discussed in this paper possess proven recoverable carbon reserves that will, if produced and emitted, intensify anthropogenic climate change and greatly exacerbate the social, political, and economic challenges related to it (Carbon Tracker 2011). Analysis based on historic emissions can also be applied to each entity's own carbon reserves and shares of its future carbon production that would need to be captured and stored (or offset by other means) in increasing percentages per annum (Allen et al. 2009a).

Indeed, the entities identified in this analysis hold two important assets-production capacity and proven recoverable reserves - that, together with profit motives and tax and regulatory incentives to discover and produce new fossil fuel reserves, hold the key to future 
fossil fuel production and emissions (Allen et al. 2009b), and thus, arguably, the future of the planetary climate system. The International Energy Agency has concluded that "no more than one-third of proven reserves of fossil fuels can be consumed prior to 2050 if the world is to achieve the $2{ }^{\circ} \mathrm{C}$ goal" (IEA 2012b); most of these reserves are in the hands of carbon majors. Redoubling international efforts to secure an effective climate agreement will likely prove insufficient unless some means can be found to involve the carbon majors in the effort to keep their reserves in the ground or commensurate efforts to prevent or offset their emission to the atmosphere.

\section{Conclusion}

The analysis presented here focuses attention on the commercial and state-owned entities responsible for producing the fossil fuels and cement that are the primary sources of anthropogenic greenhouse gases that are driving and will continue to drive climate change. The results show that nearly two-thirds of historic carbon dioxide and methane emissions can be attributed to 90 entities.

This analysis offers a somewhat different perspective on the causes of and responsibility for dangerous anthropogenic interference in the climate system. Without minimizing the responsibility of Annex I nations, nor of China and India, often discussed, this analysis highlights the role of some non-Annex I nations, such Saudi Arabia, Venezuela, Mexico, Iran, Kuwait, Abu Dhabi, Libya, Nigeria, Indonesia, Brazil, and other countries that have not been at the center of discussions regarding responsibility for controlling emissions. Some of these nations are, in their role as carbon producers, as important contributors to climate change as the Annex I nations who until now have been the focus of attention.

Most analyses to date, as well as the UNFCCC structure, consider responsibility for climate change in terms of nation-states. Such analyses fit the framework of international law, insofar as treaties and conventions are based on agreements between nationstates. However, responsibility can be understood in other ways as well, as done in the present analysis tracing emissions to major carbon producers. Shifting the perspective from nation-states to corporate entities-both investor-owned and state-owned companies - opens new opportunities for those entities to become part of the solution rather than passive (and profitable) bystanders to continued climate disruption. Future work (Heede and Oreskes, in prep.) will examine the question of ethical, political, and legal arguments to enlist or require these carbon majors in limiting further dangerous anthropogenic interference with the climate system. Social pressures may be brought to bear on investor-owned entities, which could work as an additional lever to push action to reduce greenhouse gas emissions or removing $\mathrm{CO}_{2}$ from the atmosphere. Regulation, litigation, and shareholder actions targeted at the private entities responsible for tobacco-related diseases played a significant role in the history of tobacco control; one could imagine comparable actions aimed at the private entities involved in the production of fossil fuels, particularly insofar as some of the entities included in this analysis have played a role in efforts to impede legislation that might slow the production and sale of carbon fuels. Energy companies have strong financial incentives to produce and market their booked reserves and oppose efforts to leave their valuable assets in the ground (Grantham 2012), but social and legal pressures may shift these incentives. Identifying who the major carbon producers are, and have been historically, may provide a useful basis for future social and legal pressure. 
Acknowledgments I am very grateful to Naomi Oreskes, Brenda Ekwurzel, Peter Frumhoff, and Carroll Muffett for their insightful comments on this manuscript. I also want to thank Gregg Marland and Kornelis Blok for helpful reviews of the methodology. I gratefully acknowledge supporting funding from Climate Justice Programme (Sydney), and Greenpeace International (Amsterdam), (Cambridge, USA). I also thank Susan Rhea for research assistance, and Peter Roderick for initiating the progenitor of this project.

The data reported in this paper are tabulated in the Supporting Online Material and will be archived at the Climate Accountability Institute (climateaccountability.org and carbonmajors.org) website as PDFs of the fossil fuel and cement production summary histories of the 90 carbon major entities, worksheets of carbon content by fuel, non-energy uses by fuel, and emissions attributed to the 90 entities, also by fuel, and sets of summary worksheets.

Author contribution Richard Heede provided the analysis and authored the paper.

Competing financial interest statement The author declares that no competing financial interests exist.

Open Access This article is distributed under the terms of the Creative Commons Attribution License which permits any use, distribution, and reproduction in any medium, provided the original author(s) and the source are credited.

\section{References}

Allen MR, Frame DJ, Mason CF (2009a) The case for mandatory sequestration. Nat Geosci 2:813-814

Allen MR, Frame DJ, Huntingford C, Jones CD, Lowe JA, Meinshausen M, Meinshausen N (2009b) Warming caused by cumulative carbon emissions towards the trillionth tonne. Nature 458:1163-1166

Baer P, Harte J, Haya B, Herzog AV, Holdren J, Hultman NE, Kammen DM, Norgaard RB, Raymond L (2000) Equity and greenhouse gas responsibility. Science 289:2287

Baumert KA, Kete N (2002) An architecture for climate protection. In: Baumert K (ed) Building on the Kyoto protocol: options for protecting the climate. World Resources Institute, Washington, DC, pp $1-30$

Bode S (2004) Equal emissions per capita over time - a proposal to combine responsibility and equity of rights for post-2012 GHG emission entitlement allocation. Eur Environ 14:300-316

Broecker W (1975) Climatic change: are we on the brink of a pronounced global warming? Science 189:460-464

Busby JW (2007) Climate change and national security: an agenda for action. Council on Foreign Relations, $40 \mathrm{pp}$

Carbon Tracker (2011) Unburnable carbon: are the world's financial markets carrying a carbon bubble? Investor watch, London; carbontracker.org

Coburn J, Donahue SH, Jayanti S (2011) Disclosing climate risks: a guide for corporate executives. Attorneys \& Directors. Ceres, Boston, 42 pp

den Elzen M, Fuglestvedt J, Höhne N, Trudinger C, Lowe J, Matthews B, Romstad B, de Campos CP, Andronova N (2005) Analysing countries' contribution to climate change: scientific and policy-related choices. Env Sci Pol 8:614-636

European Commission Joint Research Centre (2011) Global emissions EDGAR v4.2: methane emissions. Emission Database for Global Atmospheric Research (EDGAR). Ispra, Italy. edgar.jrc.ec.europa.eu/ overview.php? $\mathrm{v}=42$

Fleming JR (2005) Historical perspectives on climate change, Oxford University Press

Gardiner SM (2004) Ethics and global climate change. Ethics 114:555-600

Gardiner SM (2011) A perfect moral storm: the ethical tragedy of climate change. Oxford University Press

Gardiner SM, Caney S, Jamieson D, Shue H (2010) Climate ethics: essential readings. Oxford University Press

Global Commons Institute (2008) Carbon countdown: a campaign for contraction \& convergence, GCI, London, www.gci.org.uk/

Grantham J (2012) Be persuasive. Be brave. Be arrested (if necessary). Nature, 491, online 14Nov12

Hancock EE (2005) Red dawn, blue thunder, purple rain: corporate risk of liability for global climate change and the SEC disclosure dilemma. Georgetown Int Environ Law Rev 17:223-251

Heede R (2013) Carbon majors: accounting for carbon emissions 1854-2010. Methods \& Results Report, 98 pp. Annex B: Methodology. Climate Mitigation Services, Snowmass, CO, www.climatemitigation.com 
Hoeppe P (2011) Extreme weather events: are their frequency and economic impact rising? Climate change and water investment conference, London, 6 June 2011, Geo Risks Research, Munich RE, Munich, www.munichre.com

Höhne N, den Elzen MGJ, Weiss M (2006) Common but differentiated convergence (CDC), a new conceptual approach to long-term climate policy. Clim Pol 6:181-199

Höhne N, Hare B, Schaeffer M, Chen C, Rocha M, Vieweg-Mersmann M, Fekete H, Rogelj J, Macey K, Fallasch F (2011) Negotiations heading towards high warming, high cost pathway. Climate Analytics, Berlin; climateanalytics.org

Intergovernmental Panel on Climate Change (1996) Climate change 1995, second assessment Rpt, The science of climate change, IPCC Working Group I, Cambridge Univ. Press, 572 pp

Intergovernmental Panel on Climate Change (2006) 2006 IPCC guidelines for National Greenhouse Gas Inventories: vol. 2: energy (stationary, mobile, and fugitives), vol. 3: Industry. IPCC, Geneva. ipcc-nggip. iges.or.jp/public/2006gl

Intergovernmental Panel on Climate Change (2007) In: Core Writing Team, Pachauri RK, Reisinger A (eds) Climate change 2007: synthesis report. Contribution of working groups I, II and III to the fourth assessment report of the intergovernmental panel on climate change. IPCC, Geneva

Intergovernmental Panel on Climate Change (2013) Climate Change 2013: the physical science basis, summary for policy makers. WG1 contribution to IPCC AR5, 27 September 2013, 36 pp

International Energy Agency (2012a) "Global carbon-dioxide emissions increase by $1.0 \mathrm{Gt}$ in 2011 to record high.” (IEA newsroom, Paris, 24 May)

International Energy Agency (2012b) World Energy Outlook 2012. IEA, Paris, www.iea.org

International Petroleum Industry Environmental Conservation Association, \& International Association of Oil and Gas Producers (2011) Energy efficiency: improving energy use from production to consumer. IPIECA \& OGP, London

Jamieson D (2009) Climate change, responsibility, and justice, science and engineering ethics; online 22Oct09; doi:10.1007/s11948-009-9174-x

La Rovere EL, de Macedo LV, Baumert KA (2002) The Brazilian proposal on relative responsibility for global warming. In: Baumert K (ed) World Resources Institute: Building on the Kyoto Protocol: options for protecting the climate, Washington, DC. pp 154-174

Lovins AB (2011) Reinventing fire: bold business solutions for the New Era, Chelsea Green, 352 pp

Marcel V (2006) Oil titans: national oil companies in the Middle East, Chatham House, London. Brookings Institution Press, Washington, $322 \mathrm{pp}$

Marland G, Rotty R (1984) Carbon dioxide emissions from fossil fuels: a procedure for estimation and results for 1950-1982. Tellus 36b:232-261

Marland G, Boden TA, Andres RJ (2011) Global, Regional, and National $\mathrm{CO}_{2}$ Emissions. In Trends: A Compendium of Data on Global Change, CDIAC, Oak Ridge Natl. Lab., U.S. DOE, cdiac.esd.ornl.gov/ frequent_data products.html

Matthews WH, Kellogg WW, Robinson GD (1971) Inadvertent climate modification: study of man's impact on climate (SMIC). MIT Press, Cambridge

Matthews HD, Gillett NP, Stott PA, Zickfeld K (2009) The proportionality of global warming to cumulative carbon emissions. Nature 459:829-832

National Research Council (1979) Carbon dioxide and climate: a scientific assessment, report of an ad hoc study group on carbon dioxide and climate. Woods Hole, 23-27 July. NRC, Washington

Neumayer E (2000) In defence of historical accountability for greenhouse gas emissions. Ecol Econ 33:185-192

Olivier JGJ, Janssens-Maenhout G, Peters JAHW (2012) Trends in global $\mathrm{CO}_{2}$ emissions, 2012 report. Netherlands Environmental Assessment Agency; edgar.jrc.ec.europa.eu/CO2REPORT2012.pdf

Oreskes N, Conway E (2010) Merchants of doubt: how a handful of scientists obscured the truth on issues from tobacco smoke to global warming. Bloomsbury Press, New York

Peters GP, Marland G, Le Quéré C, Boden T, Canadell JG, Raupach MR (2012) Rapid growth in $\mathrm{CO}_{2}$ emissions after the 2008-2009 global financial crisis. Nat Clim Chang 2:2-4

President's Science Advisory Committee (1965) Restoring the quality of our environment, report of the environmental pollution panel. The White House, Washington, DC

Ringius L, Torvanger A, Underdal A (2002) Burden sharing and fairness principles in international climate policy. Int Environ Agreements: Polit, Law Econ 2:1-22

Rive N, Torvanger A, Fuglestvedt J (2006) Climate agreements based on responsibility for global warming: periodic updating, policy choices, and regional costs. Glob Environ Chang 16:182-194

Rogelj J, Nabel J, Chen C, Hare W, Markmann K, Meinshausen M, Schaeffer M, Macey K, Höhne N (2010) Copenhagen accord pledges are paltry. Nature 464:1126-1128

Schiermeier Q (2012) The Kyoto protocol: hot air. Nature 492:656-658

Smith KR, Desai MA, Rogers JV, Houghton RA (2013) Joint $\mathrm{CO}_{2}$ and $\mathrm{CH}_{4}$ accountability for global warming. Proc Natl Acad Sci, online 11 July 2013, E2865-E2874 
Stern DI, Kaufmann RK (1998) Annual estimates of global anthropogenic methane emissions: 1860-1994. Oak Ridge Nat. Lab., Carbon Dioxide Information Analysis Center (CDIAC). U.S. DOE, Oak Ridge, TN. cdiac. esd.ornl.gov/trends/meth/ch4.htm

U.S. Environmental Protection Agency (1983) Can we delay a greenhouse warming? The effectiveness and feasibility of options to slow a build-up of carbon dioxide in the atmosphere, by Stephen Seidel \& Dale Keyes, 2nd Corrected Edition, Washington, DC

U.S. Environmental Protection Agency (2011) Global anthropogenic non- $\mathrm{CO}_{2}$ greenhouse gas emissions: 19902030, draft. Climate Change Division, EPA 430-D-11-003. EPA, Washington

U.S. Environmental Protection Agency (2012a) Inventory of U.S. greenhouse gas emissions and sinks: 19902010. 15 April, EPA, Washington. www.epa.gov/climatechange/emissions/usinventoryreport.html

U.S. Environmental Protection Agency (2012b) Inventory of U.S. greenhouse gas emissions and sinks: 19902010, Annex 2.3: methodology for estimating carbon emitted from non-energy uses of fossil fuels, Table A58: fuel types and percent of C stored for non-energy uses; Tables A-256 and A-257

United Nations (1992) United Nations framework convention on climate change, Articles 3 and 2. New York. unfccc.int/resource/docs/convkp/conveng.pdf

United Nations (2012) Energy statistics yearbook 2009. UN statistics division, New York. unstats.un.org/unsd/ energy/yearbook/default.htm

Victor DG (2009) Global warming: why the $2{ }^{\circ} \mathrm{C}$ goal is a political delusion. Nature 459:909

Victor DG (2011) Global warming gridlock: creating more effective strategies for protecting the planet. Cambridge Univ Press, New York

Victor DG, Hults D, Thurber M (eds) (2012) Oil and governance: state-owned enterprises and the world energy supply, Cambridge University Press

Weart SR (2003) The discovery of global warming. Harvard Univ Press, Cambridge

Wei T, Yang S, Moore JC, Shi P, Cui X, Duan Q, Xu B, Dai Y, Yuan W, Wei X, Yang Z, Wen T, Teng F, Gao Y, Chou J, Yan X, Wei Z, Guo Y, Jiang Y, Gao X, Wang K, Zheng X, Ren F, Lv S, Yu Y, Liu B, Luo Y, Li W, Ji D, Feng J, Wu Q, Cheng H, He J, Fu C, Ye D, Xu G, Dong W (2012) Developed and developing world responsibilities for historical climate change and $\mathrm{CO}_{2}$ mitigation. Proc Natl Acad Sci U S A 109:12911-12915

World Bank (2008) A citizen's guide to national oil companies, part a: technical report, and part B: data directory, . World Bank, Washington, \& Center for Energy Economics, Bureau of Economic Geology, University of Texas, Austin

World Bank (2012a) Estimated flared volumes from satellite data, 2006-2010. World Bank Global Gas Flaring Reduction. World Bank, Washington. http://go.worldbank.org/D03ET1BVD0

World Bank (2012b) Turn down the heat: why a $4{ }^{\circ} \mathrm{C}$ warmer world must be avoided, by the Potsdam Institute for Climate Impact Research, and Climate Analytics, climatechange.worldbank.org

World Business Council for Sustainable Development, Cement Sustainability Initiative (2011) $\mathrm{CO}_{2}$ and energy accounting and reporting standard for the cement industry; WBCSD, Geneva, and related materials posted at www.wbcsdcement.org

World Coal Association (2005) The coal resources: a comprehensive overview of coal, London, worldcoal.org/ resources/wca-publications

World Meteorological Organization (1976) WMO statement on climatic change, adopted by the WMO executive committee, and technical report by the WMO executive committee panel of experts on climatic change. WMO, Geneva

Zickfeld K, Eby M, Matthews HD, Weaver AJ (2010) Setting cumulative emission targets to reduce the risk of dangerous climate change. Proc Natl Acad Sci U S A 106:16129-16134 